\title{
Environmental Implications of Promotional Campaigns in Enugu Metropolis
}

\author{
Charles Eze Obeta ${ }^{1}$, Prof. Ogwo E. Ogwo ${ }^{2}$ \\ Department Of Marketinguniversity Of Nigeria Enugu Campus, Enugu Nigeria. \\ Department Of Marketingabia State University, Uturu, Abia State, Nigeria
}

\begin{abstract}
An obvious fallout from today's global world is the increased domination of marketing space and practice by promotions. This has resulted in greater use and application of promotional campaigns by organizations and individuals in affecting and influencing their targets. Prominent among these promotional tools in the recent past are posters, banners, bannerettes, fliers, handbills etc which are displayed in every nook and cranny of our immediate environment. But beyond the core aim of advancing promotional causes for either products or individual goals, these promotional materials turn out as community spoilers and pollutants as most of them are recklessly displayed and littered on the environments. This study evaluated the environmental implications of all promotional campaigns via banners, posters, fliers, handbills etc. Findings from it show serious environmental abuse, disorder, indecency and irresponsibility with their obvious environmental and health implications on the people. For this reason, we recommended greater usage of the digital signage promotional mode, effective monitoring of promotional campaign displays by relevant agencies as well as the enforcement of the "polluter-pays principle" and the payment of pollution tax by corporations, among others as remedies.
\end{abstract}

Keywords: Promotional Campaigns, Posters, Banners, Environmental Abuse.

\section{Introduction}

Promotional campaigns have become the driving force of not only the corporate world but also other individual objectives. Hardly do you find business firms or marketing organizations that don't find passion in promotional campaigns as key marketing strategies. Hence, in this age of communication-driven world, promotions drive sales reasonably because the market needs conviction in buying even the best designed and high quality (made) product. That conviction comes only through well structured and composed communication messages which promotional campaigns convey. As many scholars have rightly noted, this is the era of marketing-based communication hence the ubiquity of marketing communications in marketing practice today. In that regard, communication drives the engine of marketing and as such, "no communication, no marketing" seems a very apt slogan for marketing practice today.

No organization is left out in this apparent craze for promotion as the veritable tool in marketing practice. Organizations employ different strategies to outwit the other through various promotional methods in taking a foothold on the market and indeed controlling a higher percentage of the market share. Following from that the society is awash with lots of promotional campaigns through banners, posters, handbills, fliers and road shows etc.

Given this not-too pleasant scenario, promotional materials are gradually moving away from being corporate sponsors and promoters to becoming community spoilers and pollutants. Unfortunately, not much research interest has been show in this direction. Much rather have been concentrated on the functional positives of promotional campaigns rather than the dysfunctional angles. But Reichert (1970) in Onyeke (2003) had noted that neon signs, billboards, pamphlets, direct mails, newspapers, magazines and packaging material have become pollutants of the environment. And similarly, Mukhlyonov (1979) in Igbokwe and Mba (1997) also noted that industrial wastes to which textile mills contribute largely are a major cause of pollution worldwide. According to him, "they contain a variety of complex organic and inorganic components and their pollution and toxicity effects are of greater significance than that of domestic wastes". Onyeke (2003) painted even a grimmer picture of the environmental nuisanceness of sales promotion with insight into instances of environmental abuse and pollution inherent in corporate promotions. According to him, newly painted fence/wall in cities are covered with posters from top to bottom, and also that billboards which cost their owners huge amount of money to produce and mount are equally covered with posters sometimes by those of politicians or preachers or the adverts of film stars announcing their new albums.

That indeed is the common sight of our society or environment. It is filled up with discomfiting sights of promotional abuses, degradation, uncleanliness and pollution from banners, posters, handbills, fliers and even billboards etc. The indiscriminate and irresponsible display and littering of the environment with these promotional materials are matters of concern. And that is clearly the focus and challenge of this study which is 
inspired by the fact that environmental pollution and promotional campaign studies and researches have rather narrowed themselves to other angles to the exclusion of these very important highlighted angles.

It is therefore against the backdrop of this increasing promotion - pollution-generated trend which does not show any flicker of abatement given that we do not yet have strong consumer movements that could challenge corporations to high environmental performance and responsibility that inspired this study. It is thus an attempt to make a quantitative and qualitative assessment of the volume and nature of all forms of promotional campaigns through banners, posters, bannerettes, fliers and handbills by corporate and individual campaigners which are seen in every part of our street.

\section{Statement of the Problem}

Environmental issues and pollution have more often been viewed from a much narrower angle. In our common understanding and knowledge of them, we quickly run our minds only to such angles like oil and gas spills/flaring, toxic waste and dumping, soil water and air pollutions, land degradations, deforestation etc as the most common sources of environmental pollutions. Similarly, we view corporate pollutions from the productrelated angles. This apparent myopic view has thus, wrongly shown big time multinational corporations within the oil and gas sector as the only habitual environmental culprits/offenders. And wrongly too, our pollution prevention action plans continually miss the mark hence the unabated environmental pollution. In effect, our pollution prevention approaches have followed an incomprehensive pattern resulting to our inability to attain the desired environmental decency feasible only when all pollution sources have been fully identified and holistically addressed.

Hardly have we given thought to other subterranean and subtle contributors to our environmental problem. In all nooks and crannies, we often find the pervasive intrusions of promotional campaign materials in the form of banners, posters, handbills, fliers and road shows. These forms of promotion especially the road shows, undoubtedly, often cause impregnable road traffic problems while the other printed forms generate variants of environmental hazards within our streets, roads and public places as they commonly litter and rot in these arenas/sites.

In today's obviously promotion-driven corporate world, promotion-generated pollutions are therefore quite imaginable. The environmental havocs and damages from such are equally obvious. From the careless and irresponsible display/spread of the printed promo-materials which, by content, contain traces of toxicity given the technology of their production process, the argument becomes more tenable and worrisome too.

So do these promotional prints, often left to rot in these public places of display, add any value or inflict some havoc to the society?. Obviously the latter especially in a developing economy like ours that is bereft of appropriate regulation for order, decency and good taste. And do these corporate promoters provide commensurate social investments to the society that could make up for the obvious environmental havocs resulting from their frequent wide scale promotions?

\section{Research Objectives:}

The following research objectives are hereby formulated to guide the study:

i. To determine the nature and volume of all promotional campaign materials

ii. To determine the peak and off-peak periods in the display of these promotional campaign materials.

iii. To determine the extent of value creation or otherwise in the display of the promotional campaign prints.

iv. To determine the degree of environmental hazards resulting from the display of the promotional campaign materials

v. To determine the degree of decency, order and good taste in the display of the promotional campaign materials in our public places.

\section{Theoretical Foundation of the study}

This study draws its theoretical support from the Triple A (AAA) model of Environmental Public Relations practice by Nwosu (2003) in Nwosu \& Uffoh (2005). Environmental Public Relations (EPR) is defined as the deliberate, systematic and sustained application of public relations models, strategies/techniques and philosophy in managing all activities (eg. campaigns and projects) aimed at protecting and preserving the environment for the human beings of today and tomorrow as well as managing the issues and problems arising from the above activities and offering practical solutions to them.

The Triple A (AAA) according to Nwosu \& Uffoh (2005) is an EPR model standing out for Awareness, Acceptance and Adjustment which is considered most suitable and appropriate for all antipollution campaigns, and environmental management issues. According to the model, the best strategies towards executing any environmental or anti-pollution campaign is by first creating adequate awareness of the problem, issues or desired changes through a well-researched, planned and executed awareness campaign in 
phases of communication action-plans that start and end with the target population of the campaign. The knowledge of the subject by the target population then leads to their acceptance of the environmental campaign programme that has to be reinforced by well designed information, education and communication (IEC) programmes. And based on the awareness and acceptance of the environmental campaign issue, the target population would be better positioned to make the desired positive adjustments in their behaviours which thus bring about success in the environmental campaign. The Triple A (AAA) model therefore merely emphasizes the need for greater awareness campaign on all environmental issues for the peoples' awareness, acceptance and life adjustments. Obviously such awareness programmes would correct the current forms of abuses of the environment and go a long way to reducing the inherent effects.

\section{Review of Literature}

Literatures covering Environmental policies, Promotion Pollution, Promotion Effects and Primary Technology Effects of promotional materials were generally reviewed in the study. Research evidences from Upperbrink (1991) and Okorodudu-Fubara (1991) gave insights into environmental policy and its late commencement in Nigeria. The delay in putting into place the environmental policy denied the country a number of environmental benefits and in consequence contributed to the abuses and pollution inherent in our environment (Ekpo \& Umoh, 2003).

Studies by Udeze (2005) and Omeje (2008/2009) fully capture the ubiquity of promotion campaign materials like posters, banners, handbills etc which dot out environment. The ubiquitous presence of these promotional materials is perhaps the aftermath of the long absence of the environmental policy in Nigeria. But the serious gap created by that seems being filled up by the establishment in 2007 of relevant environment agencies like the national Environmental Standards and Regulations Agency (NESREA) and the earlier created Federal and States Ministries of Environment (www.nesrea.org/about.pap).

The consequences of environmental abuse by the promotional campaign materials of posters and banners etc are traceable to their source and chemical process of paints, synthetic fibres and lead (Ugwuegbu, 2003; Awake, 1998 and Wilson, 1994). These especially lead to a range of health hazards from toxic and chemical discharges that are injurious to the body as noted by Adinna (2001). The degree of environmental pollution by these campaign materials and the enormity of their health implications can be gleaned from the quantum of promotional campaigns in our environment today.

\section{Methodology/Procedure}

As a descriptive study, it applied the survey design which has been well articulated by Eboh (2009) and Selltiz et al (1976) in Agbonifoh and Yomere (1999). Beyond that the study further used the observation and interview methods with physical visits by the researcher and four of his Survey Assistants to major promotional materials' display sites in Enugu and interview of relevant stakeholders. The interview covered staff of the Health and Environment ministries of Enugu state, staff of Partnerships for Transforming Health Systems (PATHS) in Enugu and some close residents of the promotional display sites. The survey visits covered display areas within the Enugu city centre, Abakpa, Uwani, Achara Layout and GRA. The major interest of the survey team in the promotional materials' display sites in those areas in line with our core research objectives was to find out the following:

i. The quantum or quantity of promotional materials' display on the streets/roads

ii. The level of decency or defacements in display outlooks

iii. The average distance or gap in-between the display areas.

iv. Extent of littering or droppings of promotional materials at display areas and the accompanying effects.

\section{Scope of the study}

In view of the usual constraints and limitations on researches which preclude them from full coverage of an entire study scope, our focus of interest in this study is only on banners, bannerettes, posters, fliers, handbills and flags as we hardly can effectively study the entire promotional campaigns.

\section{Area of study}

This study is limited to Enugu metropolis as our study area. According to Ubani and Ezeadiche (2009), Enugu lies approximately on latitude $06^{\circ} 21^{\circ} \mathrm{N}$ and $06^{\circ} 30^{\circ}$ and longitude $07^{\circ} 26^{\circ} \mathrm{E}$ and $07^{\circ} 37^{\circ} \mathrm{E}$. It has an estimated land area of about 72.8 square kilometers. Enugu has a total land area of 12,831 kilometers and is the state capital of Enugu State of Nigeria. Residential land use account for the highest land use comprising about $54.3 \%$ of total urban area in Enugu and 20 district neighborhoods that may be broadly categorized as low, medium and high density areas make up the city. 


\section{Population of Study/Sample}

As noted by Onodugo, Ugwuonah and Ebinne (2010 and Nwodu (2006), population of study is not limited to human beings alone but equally consists of other living and non-living things. Our population for this study therefore includes all the posters, banners, fliers and other promotional items, plus the various outdoor stands dotting the entire landscape of Enugu city. These promotional items are littered and scattered in major sites and locations in the city. And given the manner in which they are displayed sometimes on-top of existing ones, determining their actual or exact figure is an obvious difficulty. Therefore, it is considered to be an infinite population.

\section{Discussion and Findings}

As already stated, this is an observation-based study. This is in view of the fact that the environmental effects of promotional campaign materials like posters, fliers, banners, bannerettes, handbills etc can best be assessed/or determined through observation of major display sites in the city rather than mere opinions of perhaps even non-observers. It took the researcher and his survey Assistants six days to fully cover the identified flashpoints of promotional displays in Enugu from where we obtained the following findings.

Evidence from all the major display sites visited shows that majority of the posters and banners on display fall within the political, religious, Nollywood entertainment and product or corporate promotions. For instance, at the Nnamdi Azikiwe stadium, political campaign posters of major political candidates in all the parties from the President to the House of Assembly members in Enugu State compete over the other for space while at the P\&T axis, it is more of the posters of Nollywood entertainers. Beside these ones, we still found corporate promotional posters from Etisalat, Globacom, Nigerian Breweries, Coca Cola, Pepsi and MTN most especially at the Ogbete Market display axis. Classification of these various promotional materials we found has been illustrated by our Table I below in the order of their dominance. In their dominance level, the political campaign posters first, then the religious, Nollywood and the corporate/product promotion posters take that order.

Table 1: Different Classes of the Promotional Materials

\begin{tabular}{|l|l|l|l|}
\hline & Classification & Content type & Degree of display \\
\hline 1 & Political & Displayed posters by politicians & Massively displayed \\
\hline 2 & Religious & All banners \& posters by religious organizations & Spatially displayed \\
\hline 3 & Nollywood & Posters on new releases by Nollywood actors & Not massively displayed \\
\hline 4 & Corporate & All product or service promotional posters by companies & Skeletally displayed \\
\hline
\end{tabular}

\section{Source: Field Survey}

We also found out that the promotional materials do not command any decency or good order in their displays or pasting. Our survey found out that the posters and banners are displayed on every available fence walls and buildings, electric poles, sign posts, billboards or refuse bins. It was further found that lots of them are littered on the ground with a good number in the gutter which has obvious drainage implications in the city. Sample excerpts depicting the absurdity of posters/banners in some display sites in comparison with nonpostered areas in Enugu are displayed as photo album in our Appendix III. While our Table II below shows the major objects or platforms on which these promo-materials are recklessly displayed. A number of the residents interviewed around these display sites expressed their anger over the disorderly manner the promotional materials are pasted/displayed and stated that that was only possible in Nigeria. They condemned the unguided and reckless way of displaying these promotional materials.

Table II: Major Objects on which adverts were Displayed
\begin{tabular}{|l|l|l|}
\hline & Display objects & Degree/extent of display \\
\hline 1. & Walls/fence & Very high- virtually all places \\
\hline 2. & Residential building & High \& low depending on location of building \\
\hline 3. & Refuse bins & Low \& high depending on location \\
\hline 4. & Sign Posts/Billboards & High depending on location. \\
\hline 5. & Electric poles & Low (Generally few) \\
\hline 6. & Immovable cars & High \& low depending on location of car \\
\hline
\end{tabular}

Source: Field Survey

Our survey equally found out that these materials are mostly displayed or pasted at very odd times like late nights or early mornings by the "area boys" as described by one stakeholder. People who live around the display areas stated they have never met or seen the pasters of the posters. This is because it was discovered that pasting of posters or banners has fast been turning out into a brisk business for these "area boys" in town who constitute themselves into monopolists or special groups/association for the job. In essence, poster and banner 
displays are done for a fee now ranging from N500.00 and above depending on the quantity of materials for display as well as the coverage area.

In terms of the distance or gap in-between the display areas, our observation could modestly put that at an average of 30 meters. Within the display sites or locations, you find multiples and clusters of posters in a space length of averagely 20 meters. This site area covering the 200 yards in an average space length is usually filled up and fully covered with so many posters, and also few banners in some locations which make the sites very nauseating and disgusting because of the level of defacement and abuse of such areas.

According to the nearby residents to the display sites, the average days gap between old and new poster displays in all the areas visited is between 3 and 4 days. The low gap at time of our survey is attributable to the tempo of political activities then which raised both the frequency and volume of poster displays especially for political posters which greatly outnumbered other ones. While posters, banners etc do not go with strict enforcement of rules with regard to exclusive sites/locations except the objection to having them at major roundabouts, billboards go with more strict rules. Some of the few professional experts from the state Ministries of Environment and Health as well as the United Nations Agency, PATHS (Partnerships for Transforming Health Systems) that shared their views with our survey team pointed out that the new order in developed countries is largely the digital signage mode of promotions rather than our type of mode.

Presented in Table III below is the graphic picture of the nature of display of posters, banners in a few sites in the city:

Table III: Nature of Promotional Materials' Display in Enugu

\begin{tabular}{|l|l|}
\hline Site/Location & Description of Nature of Display \\
\hline 1. Nnamdi Azikiwe Stadium & Crowded display of assorted posters on walls and every available space \\
\hline $\begin{array}{l}\text { 2. UNEC Gate stretching up to Osadebe } \\
\text { Street }\end{array}$ & Spatial display of the various posters on street walls etc \\
\hline 3. P. \& T. Quarters up to Market Road & Spatial display of various posters on entertainment, religion and politics \\
\hline 4. Ogbete Market up to Old Park & $\begin{array}{l}\text { Heavy and crowded display of all forms of posters, and banners on products/services, } \\
\text { politics, religion }\end{array}$ \\
\hline 5. Mayor Junction, Achara Layout & Crowded display of various promotional materials on every available space at the site. \\
\hline
\end{tabular}

\section{Source: Field Survey}

Our survey findings further show that virtually every nook and cranny of the city is covered with posters and banners of varying sizes which cumulatively deface rather than beautify the town. In this time of electioneering, you hardly can move a distance of say 400 yards without passing through a range of posters either for political, religious and Nollywood campaigns as well as for corporate or product promotions. It is indeed the order of the day. Our Table IV below fully illustrates the degree of display of these various promotional materials in the city.

Table IV:

Degree/Volume of Display of the Different Promotional Materials

\begin{tabular}{|l|l|l|}
\hline & Promotional type & Degree/extent of display \\
\hline 1. & Banners & Not seen in all sites but few \\
\hline 2. & Bannerettes & Seen more in uncompleted buildings \\
\hline 3. & Posters & In very high number in all sites \\
\hline 4. & Fliers & Very location specific. More in bus stops and main market axis. \\
\hline 5. & Hand bills & \\
\hline
\end{tabular}

Source: Field Survey

Handbills and fliers that are freely distributed are found to litter the entire environment especially around the major markets, motor parks and bus-stops etc where they are more commonly distributed. These pieces of printed materials are read and dropped almost instantly given the fact that our people don't fully have the sense and taste for order, good taste and decency which is why they drop and litter the environment with these promotional fliers and handbills as soon as they are through with reading them. Hence, the environment becomes the major victim or casualty of this apparent irresponsible attitude. Our Table V below has presented details of the environmental hazards associated with these promotional materials' display as observed by our team and further corroborated by those interviewed. 
Table V. Nature of Environmental Damages by the Different Promotional Materials

\begin{tabular}{|l|l|l|}
\hline & Promotional type & Environmental Damage \\
\hline 1. & Banners & $\begin{array}{l}\text { Disjointed/inappropriate placements in streets; unproportional sizes of material } \\
\text { in a number of sites - making site indecent in nature }\end{array}$ \\
\hline 2. & Bannerettes & Ditto to banners \\
\hline 3. & Posters & $\begin{array}{l}\text { High degree of defacements while on display; rough/dented walls surfaces and } \\
\text { littered ground when removed }\end{array}$ \\
\hline 4. & Fliers & Leave environment littered with the materials after distribution \\
\hline 5. & Hand bills & Ditto to fliers \\
\hline
\end{tabular}

Source: Field Survey

\section{Summary of Findings}

Our observations/findings from this study can be summarized as follows:

- The volume of poster display in the city is quite high. Banners, as well as fliers and handbills are however lesser with the fliers and handbills being found more on road paths with high human traffic like the Old Park, Holy Ghost and other major Bus-Stops.

- Political posters dominate other types in all site locations visited. This is understood in view of the current electioneering period.

- Posters in their location sites of display occupy every available space such as residential and non-residential buildings and walls or fences, electric poles, refuse bins, immovable vehicles, sign posts, statues at roundabout, billboards etc.

- The nature of the poster displays lack any sense of decency, modesty, good taste and order. Most of the posters are in disjointed and disordered manner as many are on-top of others thereby causing a high level of environmental uncleanliness, defacements and abuse.

- Surfaces of pasted posters can never return to their original form any longer even after the removal of the posters as mixture of the insoluble glue or gum and paper leave a permanent scar and damage on the surface.

- Carelessly removed posters and littered fliers or handbills as well as some unremoved banners create drainage problems because of their non-biodegradable nature and consequently cause a number of unquantifiable and indeterminable environmental hazards and damages in the city environment.

\section{Conclusion}

Based on the summary of our findings/observations, we make the following sequential conclusions:

i. It is obvious that promotional materials in the form of posters, banners, handbills and fliers etc are common promotional instruments these days. While corporate and product promotions from even big corporate organizations are part of the promotional spree, they are rather dwarfed by other promotional materials on political, religious, Nollywood or entertainment campaigns.

ii. The peak periods for promotional campaigns vary from one campaign goal/sponsor to the other. While the political promotional campaigns that dominate our study peak up more at electioneering times (in Nigeria), the religious, corporate and Nollywood campaigns record greater momentum during annual or seasonal occasions like Christmas, Easter, Sallah etc. However, our survey found out that most of all posters etc are usually displayed at late nights or early mornings when the displayers are hardly seen. By implication, this odd time of display throws up some slight security challenges in the environment.

iii. The promotional materials add no value to our environment at all. Rather than beautify the environment, these materials deface its aesthetic value via their disordered display.

iv. Most of the materials used in producing these promotional materials are non-biodegradable in nature i.e. they cannot be decomposed or rot fully into the earth. A number of them that equally litter the environment end up in the drainage tunnels and gutters thereby causing drainage problems that have obvious effects on roads and buildings in the city, causing varying degrees of pollution in the environment.

v. There is obviously no sense of decency, order and good taste in the display of the promotional materials in our public places. The way and manner in which these promotional materials are displayed in every available space including even spaces with "paste no bill" order makes for no sense of decency and order by the pasters and displayers.

\section{Recommendations}

We make the following recommendations based on the findings of the study

i. Since it is clear that much of the promoters campaign pollutions are unconsciously exhibited, payment of a pollution tax by corporations and promotion campaign sponsors which has to be graduated according to 
their levels/scope of operations as well as on the basis of their profit-after tax is necessary. Surely, this would instill and inculcate more environmental consciousness in all and sundry.

ii. There is also need for the promulgation and enforcement of the "polluter - pays principle" in Nigeria as obtainable in most developed countries. By this principle, any organization responsible for causing a burden on the environment must be made to bear the costs arising therefrom.

iii. There is strong need for the strengthening of relevant agencies and institutions on environment like the NESREA and Environment Ministries to be able to play their statutory roles without undue interference by government. This will empower them to fully execute their mandate on the environment and also operate with relevant NGOs on environment.

iv. There is also need for the mapping out of specific or exclusive sites/locations for the display or pasting of our promotional posters, banners etc. This would go a long way in promoting environmental decency and relieve the drainage tunnels of much blockades resulting from littered promotional materials.

v. In addition, there is need for full introduction of the digital signage promotional mode in our environment as currently the practice in developed countries. This would go a long way in beautifying the environment rather than the current high degree of defacements and abuse of our environment by posters and the likes

\section{References}

[1]. Adinna, E. N. (2003) "Environmental Pollution in Urban and Rural Area: Sources and Ethical Implications" In E. N. Adinna, O. B. Ekop \& V. I. Attah (eds) Environmental Pollution and Management in the Tropics, Enugu: SNAAP Press Ltd.

[2]. Adinna, E.N. (2001) Environmental Hazards And Management, Enugu: SNAAP Press Ltd.

[3]. Agbonifoh, B. A. and Yomere, G. O. (1999). Research Methodology in the social sciences and Education, Bennin-city: Uniben Press.

[4]. Ahmed, Y. A. (2008) "Waste Management in Ilorin Metropolis: Lessons For Nigerian Cities" in Journal of the Environment Vol. 3 No 4, A Publication of the School of Environmental Sciences, Federal university of Technology, Yola, July.

[5]. Ajayi, D. D. \& Ikporukpo, C. O. (2005) “An Analysis of Nigeria's Environmental vision 2010" in Journal of Environmental Policy and Planning., vol. 7 issue 4, December.

[6]. Eboh, E. C. (2009). Social and Economic Research: Principles and Methods, Enugu: African Institute for Applied Economics.

[7]. Ekpo, A. H. \& Umoh, O. J. (2003) "Economics of the Environmental Pollution Management in the Tropics" in E. N. Adina, O. B Ekop and V.I. Attah (eds) Environmental Pollution and Management in the Tropics, Enugu: SNAAP Press Ltd.

[8]. Enugu State Government of Nigeria (2007) "Ministry of Environment and Mineral Resources' Environmental Protection Policy on Outdoor Advertisement, Business \& Residential Premises Signages, and Telecommunications Mast Erection". http//www.nesrea.org/about.pap

[9]. Igbokwe, P. K. and Mba, G. O. (1997) "Toxicity Identification and Evaluation of Textile Waste - Water Effluent - A Case Study of Two Textile Mills, in Environmental Review, A Multi-Disciplinary Journal for the Environmental Sciences, Vol. 1 No 2, August.

[10]. Nwabueze, C. D. (2007) “Environmental Marketing: An Imperative to Environmental Protection and Education” In I. E. Nwosu \& O. E. Soola (eds), Communication in Global, ICTS and Ecosystem Perspectives - Insights From Nigeria, Enugu: Precision Publishers Ltd.

[11]. Nwodu, L. C. (2006) Research in Communication and Other Behavioural Sciences: Principles, Methods and Issues Enugu: Rhyce Kerex Printers.

[12]. Nwosu, I. E. \& Uffoh, V. O. (2005) Environmental Public Relations Management: Principles, Strategies, Issues \& Cases, Enugu: Institute For Development Studies, UNEC.

[13]. Okorodudu-Fubara, M. T. (1991) "Review of Existing Laws and Statements on the Environment in Nigeria" in E. O. A Aina and N. O. Adedipe (eds) The Making of the Nigerian Environmental Policy, Ibadan; University of Ibadan Press.

[14]. Omeje, S. O. (2008/2009) "Posters, Banners Bannerettes and Handbills As Media of Public Relations, Advertising and Marketing Communications" In NIPR Public Relations Journal, Vol. 5 Nos. 1 \& 2

[15]. Onodugo, V. A., Ugwuonah, G. E. and Ebinne, E. S. (2010) Social Science Research: Principles, Methods and Application, Enugu: El'Demak Publishers.

[16]. Onyeke, J. K. (2003). Marketing Promotion Management, Enugu: Lano Publishers.

[17]. Quee, W. T. (1999), Marketing Research (3 ${ }^{\text {rd }}$ Edition) Oxford: Butterworth/Heinemann.

[18]. Rishante, S. J. (2007) "An Analysis of the Poster As A Contemporary Medium of Communication in Public Relations" In NIPR Public Relation Journal, Vol. 3 No. 2.

[19]. Saunders, M., Lewis P and Tornhill, A (1997) Research Methods for Business Studies, London: Pitman Publishing

[20]. The Awake Magazine (1988), 22 December P. 2.

[21]. Ubani, O. \& Ezeadichie, N. (2009) "The Effects of School Run Phenomenon on Intra-city Movement in Enugu Urban" in Journal of Environmental Design, A Journal of the Faculty of Environmental Studies, University of Uyo, Vol. 4 Nos. 1 \& 2, NW.

[22]. Udeze, S. E. (2005) "Uses And Abuses of Posters in Public Communication in Nigeria" in International Journal of Communication, No. 2, January.

[23]. Ugwuegbu, J. U. (2003) "Chemical Pollution and Appropriate Marketing Strategies for its Reduction” in E. N. Adinna, O. B. Ekop and V. I. Attah (eds) Environmental Pollution and Management in the Tropics, Enugu: SNAAP Press Ltd.

[24]. Uppenbrink, M. (1991) "The Environmental Policy of the Federal Government in the Federal Republic of Germany" in E. O. A. Aina \& N. O. Adedipe (eds) The Making of the Nigeria Environmental Policy, Ibadan: University of Ibadan Press.

[25]. Wilson, D. (1984), The Environmental Crisis - A Handbook For All Fiends of the Earth, London: Hienemann Educational Books Ltd.

[26]. Yamane, T. (164). Statistics: An Introductory Analysis, New York: Harper and Row Publishers.

[27]. Yingling, L. (2008) "Stronger Regulation Needed to Improve Corporate Pollution Record in China", 2008 Worldwatch Institute. 